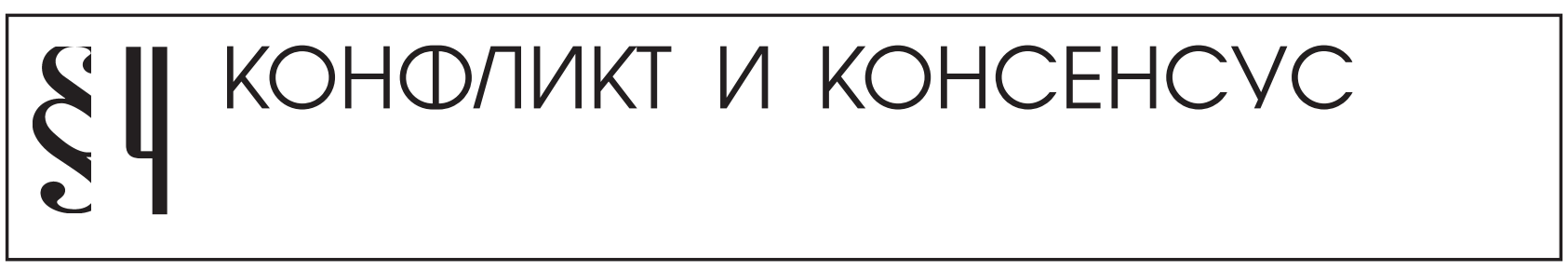

Алейников А.В.

\title{
АРХИТЕКТУРА КОММУНИКАТИВНОГО РАЗРЫВА РОССИЙСКИХ КОНФЛИКТОВ
}

\begin{abstract}
Аннотация: Статья посвящена рассмотрению конфликтогенности системной трансформации России, что требует переопределения и конкретизаџии применительно к российской специфики специфике базового понятийного аппарата современной конфликтологии, создаваемого зачастую для описания и анализа приниипиально по-другому организованного сочиума. В статье предпринята попытка выявить и проанализировать системные характеристики и основные составляющие конфликтной динамики, основные модели современной архитектуры конфликтов и специфика методологического применения «конфликтологического ключа» к анализу конфигурации институциональных схем описания современной внутригражданской, соииально-политической, идеологической ситуации в современной России. При анализе архитектуры конфликтной модели российского сочиума используются релевантные сочиально-философские методологические подходы для определения особенностей конфликтных взаимодействий и реальных поведенческих практик конфликторазрешения в современном российском сочиуме. Типологизированы инвариантные конфликтные ситуации определенного типа, их структура, свойства и особенности, а так же совокупность выработанных и используемых приемов конфликторазрешения, наборов стереотипных сиенариев конфликтного поведения и стратегии политического конструирования реальности, создающей «бесконфликтный мир и стабильность» для граждан с помощью сочиальных конструктов, идейно-символической системы.
\end{abstract}

Review: The article is devoted to the conflictogenity of the systems transformation of Russia. This requires to develop and specify a new conceptual framework of modern conflict resolution studies which would take into account specifics of Russian conflicts because usually the conceptual framework of conflict resolution studies serve to describe and analyze a differently organized society. The author of the article tries to define and analyze systems characteristics and the main elements of the conflict dynamics, the basic models of the modern architecture of conflicts and peculiarities of applying the method of the 'conflictological key' to the analysis of institutional schemes of description of modern interstate, socio-political and ideological situations in modern Russia. When analyzing the structure of the conflict model of the Russian society, the researcher as used applicable socio-philosophical methodological approaches for the purpose of defining peculiarities of conflicts and actual behavioral practices of conflict resolution in the modern Russian society. The researcher offers a classification of invariant conflict situations of a certain type, their structure, features and peculiarities as well as a combination of established and effective methods of conflict resolution, stereotype scenarios of conflict behavior and strategies of political design of reality creating the 'conflict-free world and stable life' for citizens by using social constructs and the system of ideas and symbols. Ключевые слова: Россия, конфликт, конфликтогенность, конфликтная модель, стабильность, общество, политика, власть, конфликтная динамика, коммуникация.

Keywords: Russia, conflict, conflictogenity, conflict model, stability, society, politics, government, conflict dynamics, communication.

И сследование истории российских кейсов деконструкции и разрушения социума зачастую ограничивается спекулятивным анализом «элитных интриг, клановых раскла- дов и иностранных интересов» ${ }^{1}$. Подобное реду-

${ }^{1}$ Дерлугьян Г. Как устроен этот мир. Наброски на макросоциологические темы . М.: Изд. - во Института Гайдара, 2013,С.196 


\section{Политика и общество 9 (117) • 2014}

цирование не позволяет выявить такую специфику российского конфликтного взаимодействия, как отсутствие социальной динамики в движении от «токсичных» видов социальных конфликтов, не поддающихся институционализации и несущих угрозу существованию общества, в сторону по преимуществу «позитивных», не приводящих к разрушению социума, механизмов неконфликтных изменений и конфликтов, поддающихся институционализации.

Между тем, необходим анализ изменений, по формуле Т. Парсонса, «институционализированных стандартов» ${ }^{2}$ нормативной конфликтологической культуры российского общества и глубинного архетипа «конфликтологического разума» российского народа, влияющего на « токсично-конфликтогенный» ${ }^{3}$ тип нашего развития ${ }^{4}$.

Конфликтная трактовка социальных изменений, согласно Х. Йоасу и В. Кнеблю ${ }^{5}$, основана на неприятии интерпретации конфликтов как психологически обусловленных явлений, как индивидуальных ошибочных действий или даже «болезни». Это было вызвано тем, что в данной теоретической традиции состояние статус-кво в обществе рассматривалось как некая норма, а отклонения от него могли трактоваться лишь как нарушения. Для нас инструктивный характер имеет рассуждение Г. Зиммеля о том, что «все проблематичные явления заставляют нас лучше осознать то обстоятельство, сколь невообразимо противоречиво наше настоящее... Одни только филистеры могут полагать, что конфликты и проблемы существуют для того, чтобы быть разрешенными. И те, и другие имеют в обиходе и истории жизни еще другие задачи, выполняемые ими независимо от своего собственного разрешения. И ни один конфликт не существовал напрасно, если время не разрешит

\footnotetext{
2 Парсонс Т. О структуре социального действия. М.: Академический проект,2000,С.701

3 В терминологии Дэвида Лэндеса «Существуют культуры, которые я называю токсичными... они калечат тех, кто держится за них» (Culture Counts: Financing, Resources, and the Economics of Culture In Sustainable Development // The World Bank. Washington, DC, 2000. P. 30.)

${ }^{4}$ Алейников А.В. Институциональные российские конфликты:»трагедия соревнующихся невозможностей»//Конфликтология,2012,№3.

${ }^{5}$ Йоас Х., Кнебль В. Социальная теория. 20 вводных лекций. -СПб.: Алетейя, 2011.
}

его, а заменит его по форме и содержанию другим» ${ }^{6}$ По Л. Козеру ${ }^{7}$, конфликты «очищают воздух» и могут служить предохранительным клапаном. Не каждый конфликт обязательно сопровождается выбросом агрессии, а отсутствие конфликтов вовсе не говорит о стабильности социальной системы, т. к. существуют латентные противоречия, которые могут впоследствии неконтролируемым образом выплеснуться наружу. Наоборот, открытое протекание конфликта может быть признаком стабильности. Козер утверждал, что конфликты зачастую оказывают позитивное воздействие на общества в целом, поскольку они и способствуют созданию новых правил и институтов. Если общества не допускают появления конфликтов, они в долгосрочной перспективе имеют мало шансов на выживание. Конфликт предотвращает «окостенение» социальной системы, принуждая ее к инновациям и креативности.

Рейнхард Бендикс, следуя веберовскому подходу, утверждал, что культура нации должна истолковываться как результат конфликтов в их историческом развитии и «сказать, что непримиримые конфликты являются эндемической чертой общества, еще не значит заявить, что общество характеризуется постоянной нестабильностью» ${ }^{8}$. Дэвид Локвуд в работе «Социальная и системная интеграция» ${ }^{9}$ доказывал, что триада «норма - консенсус - порядок» не противоположна триаде «власть - отчуждение - конфликт». В социальном мире эти два комплекса всегда взаимосвязаны очень специфическим и в каждом обществе совершенно особым образом. Очевидно, нужно четко различать два комплекса проблем: имеют ли место в данном обществе борьба и конкуренция между акторами или группами и классами - это один вопрос; но приведет ли это к фактическому изменению структуры данного общества - это уже другой вопрос. Вполне возможна такая ситуация, когда в обществе существует множество противоречий или системных проблем,

6 Зиммель Г. Избранное. Созерцание жизни. - М., СПб.: Центр гуманитарных инициатив, Университетская книга, 2014,C.330

${ }^{7}$ Козер Л. Функции социального конфликта : пер. с англ. О. А. Назаровой. - М.: Идея-Пресс; Дом интеллектуальной книги,2000.

${ }^{8}$ Вебер М. Избранное. Образ общества. - М.: Центр гуманитарных инициатив, 2012.С.601

${ }^{9}$ Lockwood D. Social Integration and System Integration // Explorations in Social Change. - London: Routledge \& Kegan Paul, 1964 
которые, однако, никак не проявляются на уровне действия - в этом случае мы не увидим явных протестов, открытых конфликтов, классовой борьбы и т. д. И, наоборот, в обществе могут возникать протесты и конфликты, не ведущие, однако, к изменению отношений между подсистемами общества, к изменению его общей структуры. По Никласу Луману ${ }^{10}$, потенциальная конфликтность - атрибутивная черта и естественное состояние всех социальных систем.

Степень актуализации конфликтного потенциала варьируется и зависит от степени дифференциации системы и ступени ее эволюции. Сам же конфликт является, в свою очередь, ресурсом коммуникативной эволюции общества. Конфликты в правовых обществах не подавляются, их не избегают, обеспечивая каждому из них подходящую форму коммуникации с целью уклонения от их насильственного разрешения.

В работах В. М. Сергеева ${ }^{11}$ выделяются два различных идеальных типа модернизации - «органический» (североевропейский) и «конфликтный», а ряд исследователей ( например-А.А.Казанцев, директор Аналитического центра МГИМО) уточняют тенденции «конфликтного» развития:

- отсутствие развитой культуры переговорных практик, обеспечивающих канализацию социальных конфликтов в русло цивилизованной парламентской политической борьбы;

- существенные разрывы в социально-политическом и экономическом положении различных социальных акторов, которые препятствуют становлению в обществе горизонтальных связей и устойчивых каналов урегулирования конфликтов;

- отсутствие или слабая развитость «рациональной» (в веберовском смысле) бюрократии, ориентированной на минимизацию харизматического вмешательства государства в жизнь населения и на переговоры с ним;

- слабое развитие политической культуры, ориентированной на органичную стабильность формальных институтов и традиций политических систем, ориентированных на преодоление конфликтных разрывов в обществе и реализацию рационально спроектированных моделей конфликторазрешения;

${ }_{10}$ Луман Н. Социальные системы. Очерк общей теории. СПб.:Наука, 2007; Луман Н. Общество общества. - М.: Логос, 2011 .

${ }^{11}$ Сергеев В. М. Демократия как переговорный процесс. - М.: Московский общественный научный фонд, 1999.
- сильные разрывы между различными ценностными ориентациями социальных слоев, неразвитая система переговоров между ними, слабая развитость политических институтов мирного разрешения конфликтов между различными силами;

- основной силой для нейтрализации социальных конфликтов является государство, внедряющее «сверху» на макроуровне институты конфликторазрешения, которые зачастую вступают в противоречия с институтами более низких уровней или институтами в других сферах. Для различных социальных акторов создается ситуация «дилеммы заключенного», что усиливает конфликтность и асоциальное поведение..

Властвующая элита зачастую рассматривает конфликты как источник нарушения созданного ею социального порядка, нарушения, несущего угрозу, прежде всего, ее собственному существованию. Стабильность как господствующая идеологема и как принцип политики отнюдь не безобидна ${ }^{12}$. Эта идеологема, в частности, означает, что общественное развитие планируется и контролируется только государством: гражданское общество не является движителем прогресса, а лишь его «приводным ремнем». Всеобщая стабильность это, по существу, отрицание разнообразия, которое в действительности является ключевым условием поддержания стабильности общества посредством изменений, т. е. его адаптации к новым условиям.

Конфликт и порядок являются двумя равноценными состояниями общества, сменяющими друг друга. А. Турен, полагая, что конфликт должен существовать и признаваться во всех областях социальной жизни, подчеркивал: «повсюду, где существует порядок, должно существовать его оспаривание... Формирующиеся конфликты все более направляются против „суперструктур““ или, проще говоря, против порядка, ибо новая власть обладает ранее неизвестной способностью придавать себе видимость порядка, господствовать над социальной организацией в целом, над разновидностями социальной практики, вместо того чтобы запереться в укрепленных замках, дворцах или финансовых городах. Мы входим в общество, которое не может более иметь конфликты: или последние задавлены в рамках авторитарного порядка, или общество осознает себя как конфликт, оно является конфликтом, потому что оно представляет собой просто борьбу противоположных интересов за контроль над способностью общества

12 Яницкий О. Н. Социальные движения: теория, практика, перспектива. - М. : Новый хронограф, 2013. 


\section{Политика и общество 9 (117) • 2014}

воздействовать на самого себя». Он обращал особое внимание на то, что невозможно представить себе бесконфликтное существование в современном обществе, которое «становится целиком полем конфликтов... Проблемы власти и социального господства не исчезли, область структурных конфликтов только расширяется по мере того, как область священного тает в огне запланированных или организованных трансформаций» ${ }^{13}$.

Отметим и мысль Л. Козера: «Острота конфликта, грозящего „полным разрывом“ и подрывающего основополагающие принципы социальной системы, напрямую связана с жесткостью ее структуры. Равновесию подобной структуры угрожает не конфликт как таковой, а сама эта жесткость, способствующая аккумуляции враждебных чувств и направляющая их вдоль одной оси, когда конфликт всё-таки вырывается наружу» ${ }^{14}$. Как справедливо считает Р. Дарендорф, человеческая свобода «существует лишь в мире регулируемого конфликта». В этом смысле только отдельные разновидности конфликтов носят действительно разрушительный для общества и государства характер. В основном же выявление и урегулирование конфликтов дает возможность эффективно поддерживать целостность социума в процессе трансформаций.

Странным образом табуирование зиммелевской «неизбежности конфликта между текущей вперед, распространяющейся со все большей энергией жизни и застывшими в тождестве формами ее исторического выражения» рельефно артикулируется экспертами «Валддайского клуба», на площадке которого выступают первые лица страны. Их видение России исходит из аксиомы(!!!)признания приоритета созидания перед конфликтом-«конфликт как двигатель развития в нашей стране себя исчерпал» ${ }^{15}$.Здесь уместно привести известное высказывание Р. Дарендорфа: «В обществе тоталитарного типа конфликт изгоняется из области регулирования общественных отношений и заменяется единообразием и полным согласием с существующей системой власти» ${ }^{16}$.

\footnotetext{
${ }^{13}$ Турен А. Возвращение человека действующего. Очерк социологии. - М.: Научный мир, 1998.С.155-157

${ }^{14}$ Козер Л. Указ.соч.,С.184

15 Доклад Международного дискуссионного клуба «Валдай» Национальная идентичность и будущее России. Москва, февраль 2014. [Электронный ресурc].URL: http://vid1.rian. ru/ig/valdai/doklad_identichnost_RUS_ISBN.pdf(дата обращения: 16.05.2014).

${ }^{16}$ Дарендорф Р. Современный социальный конфликт // Иностранная литература. 1993. № 4. С. 237.
}

В этом смысле подход «Валддайского клуба», участники- политологи которого удачно охарактеризованы Г.О. Павловским как «сервисные лица», «подающие Системы, не владеющие предметом дебатов, который и предлагает им поведение» ${ }^{17}$, характеризует создание уникального политического дискурса стабильности, то есть незыблемого социального порядка. Политики конструируют реальность, создавая бесконфликтный мир и стабильность для граждан с помощью социальных конструктов, идейно-символической системы, меняя, по Ханне Арендт, слова, обозначающие социальную и политическую реальность, для маскировки самой реальности, что «обличает некоторую глухоту к языковым смыслам, что само по себе уже было бы достаточно серьезно, но и приводит к определенной слепоте по отношению к стоящим за этими словами реалиям» ${ }^{18}$. Иными словами, идеологема стабильности элиминирует конфликт как механизм поиска альтернатив и вариантов развития. Но конфликт, изгнанный из политических структур, изобретенных как раз для того, чтобы его институционализировать, проецируется на отрицание необходимости конфликта гражданского, продуцирующего социальные инновации. По данным Фонда общественного мнения, 90 \% граждан России за последние два года не проявляли никакой политической или гражданской активности. Весьма показателен и другой социологический индикатор-уровень предпринимательских намерений населения. Лишь 2,6\% респондентов ${ }^{19}$, как следует из российского доклада в рамках «Глобального мониторинга предпринимательства», хотели бы стать предпринимателями (последнее место из 67 стран), при этом теневую экономическую деятельность ведут 14,5\%. Любопытно, что как выяснил « Левадацентр», к проявлению предпринимательской инициативы (экономическая активность, готовность к риску и другие шумпетеровские ценности) потенциально готовы $25 \%$, но они же практически полностью увязывают возможность ее реализации с наличием каналов личных знакомств и неформальных связей.

Практически эта идеологема вырождается в социальный конструктивизм, в навязывание обществу

\footnotetext{
${ }^{17}$ Павловский Г. О. «Система РФ в войне 2014 года. De Principatu Debili» М.:Европа,2014,С.168.

${ }^{18}$ Арендт X. О насилии. М.: Новое издательство,2014,С.51.

${ }^{19}$ Схожий уровень демонстрируют Норвегия $(6,2 \%)$ и Япония $(7,1 \%)$. В странах БРИКС планируют открыть собственное дело 22\%, а в странах Восточной Европы - $21 \%$.
} 
принципов социального порядка, необходимых властвующей элите для ее самосохранения ${ }^{20}$. Речь идет не только о понимании конфликтов как источника нарушения созданного «элитой» социального порядка, несущего угрозу, ее собственному существованию, но и создании политического спроса на смещенные мысли и действия, на смещенные социальные конфликтыл. Описывая с помощью этого понятия процесс вытеснения конфликтов из сознания и их «загона в огороженную клетку», Ульрих Бек пишет о появлении имманентной тенденции «стать “обществом козлов отпущения": не опасности виноваты, а те, кто их вскрывает и сеет в обществе беспокойство. Разве очевидное изобилие не опровергает существование невидимых опасностей? Разве весь этот шум - не выдумки интеллектуалов, не утка, слетевшая с письменного стола умствующих бандитов и драматургов риска? Не скрываются ли за всем этим шпионы ГДР, коммунисты, евреи, арабы, женщины, мужчины, турки, обитатели ночлежек? Именно неуловимость угрозы и беспомощность перед ней способствуют распространению радикальных и фанатичных настроений и политических течений, которые делают социальные стереотипы и подверженные им группы населения “громоотводами” опасностей, скрытых от непосредственного восприятия и воздействия» ${ }^{21}$. При этом следует учесть, что применение вышеуказанных контуров современной концептуализации «драйверов» (движущих сил) увеличения социальной напряженности и конфликтности в обществе и «триггеров», («спусковых крючков»), т.е. малых воздействий, непосредственно провоцирующих нарушение равновесия системы, означает поворот в сложившейся в России политико-семантической ситуации превращения понятия «конфликт» в «резиноподобное понятие, которое можно растягивать и полученное использовать в своих целях» ${ }^{22}$ (Р.Макк и Р.Снайдер). В этом плане мы наблюдаем феномен, когда, широко используясь в обыденной речевой практике, понятие утрачивает свое изначальное значение и приобретает противоположные смысловые оттенки, игра в которые и «позволяет системе менять окраску и имитировать движение в разных направлениях. Фокус в следующем:

\footnotetext{
${ }^{20}$ Яницикий О Н. Указ.соч

${ }^{21}$ Бек У. Общество риска. На пути к другому модерну. М.: Прогресс-Традиция, 2000.С.92.

${ }^{22}$ Нечипоренко Л.А. Буржуазная социология конфликта. М.: Политиздат, 1982,С.38-39.
}

нужно одновременно апеллировать к разным слоям, нейтрализуя их недовольство, и создавать видимость развития, в то время как стоишь на месте» ${ }^{23}$.

Отсюда - замусоренность политической лексики черно-белыми бинарными оппозициями «наши чужие», «Россия-Европа», «патриоты- либералы» и так далее. Конфликты переходят в личностную плоскость (коммуникации не друг с другом, а друг о друге), в стремление к предельному обострению любого конфликта с установкой на блокирование диалога с противостоящей стороной в любых его формах. Любые компромиссы представляются нетерпимыми и постыдными, а правовые и моральные нормы разрешения и урегулирования конфликтов отрицаются при оценке поведения «своих» по отношению к противнику, которому приписываются все мыслимые и немыслимые злодеяния в сочетании с непременной профанацией другой стороны конфликта. Это «стилистика скандала на одесском Привозе со специфически базарным криком, задиранием подола и плевками в лицо» ${ }^{24}$, маркирующая неприятие альтернативной мировоззренческой позиции. Стороны конфликта, как правило, в том числе и путем коррекции институциональных правил, готовятся к не к компромиссу, а к максимальной напряженности, приобретающей у характер агрессивной конфликтогенности, и имеющей провоцирующий характер осложнения личной жизни. Тезис Аль Капоне «Это просто бизнес, ничего личного» переворачивается - это теперь в основном «личное»).

Конфликтное поведение становится демонстрационным, широко используются «конфликты возмездия». Правила координации и разрешения конфликтов всякий раз разные и всякий раз устанавливаются под действием силы, механизмы согласования складываются в основном на неформальном уровне. Усиление жестких силовых обертонов в управленческих практиках, распространение силовых стратегий власти с репрессивным окрасом (запрещение, предотвращение, уничтожение) минимизируют позитивные возможности конфликта.

Пенитенциарная, «наказующая» конфликтность реализуется в тезисах о «пятой колонне настоящих врагов и агентов влияния военного блока». Более того,

\footnotetext{
${ }^{23}$ Шевцуова Л. Мы: жизнь в эпоху безвременья .М. : РОССПЭН, 2014,С.14.

${ }^{24}$ Яковенко И. Г., Музыкантский А. И. Манихейство и гностицизм: культурные коды русской цивилизации. М.: Русский путь, 2010,С.68.
} 


\section{Политика и общество 9 (117) • 2014}

дискуссия редуцируется до предложений «скорректировать эту аномалию».

Возрастает аффективность конфликтов, для которой характерны нерациональная гиперреакция даже на незначительное раздражение, провоцирующее непропорциональность ответных действий - «Мы все равно покажем, кто здесь главный».

Выдающийся филолог, двоюродная сестра Борис Пастернака, Ольга Михайловна Фрейденберг, обобщая свой горький житейский опыт, выдвинула концепт склоки как методологии нашей политической рефлексии, выяснения важнейших социально-политические вопросы на языке фиксирования своих отрицательных эмоций по поводу других субъектов конфликта. «Это низкая, мелкая вражда, злобная групповщина одних против других, это ультрабессовестное злопыхательство, разводящее мелочные интриги. Это доносы, клевета, слежка, подсиживанье, тайные кляузы, разжигание низменных страстишек одних против других. Напряженные до крайности нервы и моральное одичанье приводят группу людей в остервененье против другой группы людей, или одного человека против другого. Склока - это естественное состояние натравливаемых друг на друга людей, беспомощно озверевших, загнанных в застенок. Склока - альфа и омега нашей политики. Склока - наша методология» ${ }^{25}$.

Склока, как атрибутивная черта российской политической конфликтности, транслируется в неформальные социальные механизмы и ритуалы, перекрывая каналы и мосты коммуникации, загоняя конфликты в «институциональную ловушку».

«Равновесию подобной структуры, - по Козеру, угрожает не конфликт как таковой, а сама эта жесткость, способствующая аккумуляции враждебных чувств и направляющая их вдоль одной оси, когда конфликт все-таки вырывается наружу» ${ }^{26}$.

Примеров подобного «радикализма слабости» немало в российском политическом дискурсе - при этом чем мельче(по степени реального влияния, а не формального статуса) политик, тем активнее он замещает свой дефицит властного потенциала месседжами демонстрационной конфликтности, заботясь о виртуальном впечатлении своей «крутизной». «Семанти-

25 Пастернак Б. Пожизненная привязанность. (переписка с Ольгой Фрейденберг) М.: АРТ-ФЛЕКС, 2000, [Электронный ресурс] URL:http://www.imwerden.info/belousenko/ wr_Pasternak.htm(дата обращения: 16.03.2014).

${ }^{26}$ Козер Л. Указ.соч.,С.184. ческий переход от спокойного состояния к возбужденному, - замечает Л.Гудков, - обусловлен тем, что более или менее конкретные причины и мотивы социальных и политических противоречий и конфликтов постепенно замещаются мифологическими, приобретают все более архаический вид борьбы «людей» («своих») с хтоническими силами зла или асоциальными чудовищами» ${ }^{27}$.

Вторая точка зрения, назовем ее прагматическиуправленческой, позиция исходит из мрачноватого постулата французского социолога Бернара Гурнея - «в мире существует лишь одно место, где нет конфликтов - это кладбище». Вот цитата из выступления Президента РФ на встрече с представителями непарламентских партий 20 ноября 2013 года: «Конфликты всегда есть. Понимаете, конфликта нет только на кладбище, там все тихо и спокойно. Поэтому это нормальное явление, когда есть конфликт. Вопрос в том, чтобы найти цивилизованные инструменты решения конфликта и выходить из конфликта, укрепляя общество и государство, а не разрушая его ${ }^{28}$.

Данный подход классифицирует ставки и цели различных государств в конфликтах исходя или из логики поведения в конфликте, зависящей от склонностей государства - «плохие вещи исходят от плохих государств(плохих руководителей)» ,или из логики ситуации-«плохие вещи возможны , если хорошие государства оказываются в плохом месте» ${ }^{29}$. В теоретико-познавательном аспекте возникает вопрос о том, каким же образом можно классифицировать основные конфликтные модели в современной России? Не претендуя на универсальное (вряд ли вообще возможное) решение, предложим следующую простую и операциональную аналитическую схему, используя применяемые (например, И.Б.Родионовым). в теории систем и системном анализе разработки.

Вариант первый Стороны конфликта вступают во взаимодействие, которое ведет к нанесению серьезного вреда каждой из них, пока один и не выйдет из игры. В теории игр примером является ситуация, когда два

\footnotetext{
${ }^{27}$ Pro et Contra, Май - август 2014 ,С.140

${ }^{28}$ Путин В. Встреча с представителями непарламентских партий //Президент России. Официальный сайт. 20 ноября 2013 года. URL:http://www.kremlin.ru/news/19659 (дата обращения: 14.07.2014).

${ }^{29}$ Аллисон Г., Зеликов Ф. Квинтэссенция решения. На примере Карибского кризиса 1962 года. М.: УРСС: Книжный дом «ЛИБРИКОМ», 2012,С.65
} 
автомобиля идут навстречу друг другу, и тот, который первым сворачивает в сторону, считается «слабаком». Надо создать напряжение, которое бы привело к устранению игрока. Стороны не могут ничего выиграть, и только гордость заставляет их сохранять противостояние до финальной точки, и если никто не уступает, то столкновение и фатальная развязка неизбежны.

При этом, как правило, ограничителями, красными флажками трагического исхода являются как убежденность одного субъекта конфликта в своем здравомыслии («я никогда не доведу дело до взрыва», так и уверенность другого субъекта в знании своим противником его готовности к любым решительным действиям («он остановится потому что знает - я то пойду до конца»).

Вариант второй. Стороны конфликта могут или демонстрировать свою силу, запугивая противника (стратегия голубя), или физически атаковать противника (стратегия ястреба). Если обе стороны выбирают стратегию ястреба, то они сражаются, наносят друг другу увечья. Если же одна сторона выбирает стратегию ястреба, а вторая - голубя, то первый побеждает второго. В случае, если обе - «голуби», то стороны приходит к компромиссу, получая выигрыш, который оказывается меньше, чем выигрыш «ястреба», побеждающего «голубя».

Вариант третий. Известная «дилемма заключенного» утверждает, что максимальный выигрыш достигается кооперацией, соглашением, балансом сил и интересов.

В этой архитектуре конфликт не может быть разрешен полной капитуляцией одной из сторон. От них обеих требуется не разрушение коммуникаций, а иная логика, другая этика и новая эстетика управления договороспособностью. «Дилемма заключенного» (мы понимаем всю редуцированность подобного утверждения) обобщена в категорическом императиве Канта: «Поступай так, чтобы использовать человека для себя так же, как и для другого, всегда как цель и никогда лишь как средство». Данный стиль, при котором между участниками конфликта выстраиваются «коммуникативные мосты», можно, используя концепцию американского политического философа Айрис Янг ${ }^{30}$, назвать «коммуникативной демократией». ”. Она разделяет переговорную демократию, коммуникация в

${ }^{30}$ Young I. M. Illusion and Democracy. Oxford: University Press. 200; Young, I. Justice andCommunicative Democracy. In Radical Philosophy: Tradition, Counter-Tradition, Politics. Ed. R. Gottlieb. Philadelphia, PA: Temple University Press, 1993, PP.123-143 которой основывается на строго аргументативной дискуссии, и коммуникативную демократию, которая стремится выйти за рамки только аргументативного дискурса и для которой важны все коммуникативные ресурсы, позволяющие той или иной социальной группе выразить свою позицию и социальный опыт. Именно этот коммуникативный потенциал, который может находиться в обществе в скрытом, деформированном или, напротив, открытом виде и определяет, в нашей трактовке, конфликтные стили общества.

В противоположном же стиле «коммуникативного разрыва» выстраивается такая конфигурация разрешения, вернее подавления, конфликтов, при которой она обеспечивается не в результате интериоризации социальных норм, а насильно, путем вмешательства власти.

Томас Шеллинг, тяжеловес среди разработчиков стратегии конфликта, подчеркивал, что безусловно обязательным является допущение существования у участников конфликта как общих, так и взаимно противоречащих интересов. «Чистый конфликт, в котором интересы двух противников полностью противоположны, - особый случай; он появляется в случае войны до полного истребления, но даже для войн другого типа он неприменим. По этой причине «выигрыш» в конфликте не имеет строго состязательного смысла; это не победа, одержанная над врагом. Здесь подразумевается выигрыш относительно своей собственной системы ценностей, и его можно добиться путем переговоров, компромиссов, а также избегая поступков, наносящих обоюдный ущерб» ${ }^{31}$.

Нельзя прятаться от чужих ценностей и неприемлемых идей, обосновывая, в экстазе идейной архаики истового пафоса, борьбой с ними внутреннюю и внешнюю политику и обеспечивая идейный и ценностный консенсус подавлением инакомыслия, загоняя социум(и российский ,и западный) в ограничения, разрывая логику и смысл договоренностей и обязательств, норм и правил.

Обратим внимание в этой связи внимание на рассуждения выдающегося социолога Никласа Лумана. Он подчеркивал, что «прагматический контекст учения о ценностях ведет к заблуждению, пустым является утверждение о том, что ценности имеют нормативный смысл. Не может быть речи о том, чтобы ценности могли освящать действия. Для этого они слишком абстрактны. К тому же, исходя из ситуа-

31 Шеллинг Т. Стратегия конфликта. М.: ИРИСЭН, 2007, C.17. 


\section{Политика и общество 9 (117) • 2014}

ции, в которой нужно принимать решение о поступке, они постоянно вступают в конфликт с другими ценностями. Их функция состоит только в том, чтобы в коммуникативной ситуации дать деятельности такие ориентиры, которые никем не ставится под вопрос. Ценности- суть не что иное, как в высшей степени мобильное множество точек зрения. В отличие от идей они не похожи на неподвижные звезды, но, скорее, напоминают воздушные шары, чьи оболочки приберегают, чтобы при необходимости наполнить их воздухом, в особенности по случаю праздника Исключена возможность принятия истины в качестве масштаба в сфере ценностей - (идеологий и аргументаций) - идеология совершает великие преступления, а аргументация - мелкое жульничество» ${ }^{32}$.

Но это не означает терпимость в отношении того, что заведомо неистинно, когда трезвый анализ подменяется моральным негодованием (конфликт в России - больше, чем конфликт).

Напомним о двух способах разрешения конфликтов между ресурсами, государством и гражданами, описанных Д.Нортом, Д. Уоллисом, и Б. Вайнгастом ${ }^{33}$. Они классифицируют все существующие политические устройства на два типа - государство открытого и государство ограниченного доступа («естественное государство»). В порядках «открытого доступа» конфликты разрешаются такими институтами как суд, полиция, система обеспечения социальных благ, которые эффективно обеспечивают мир и порядок. Эффективность достигается устойчивым балансом институтов и их деперсонализацией, публичным контролем над носителями легитимного насилия. «Порядок ограниченного доступа» характеризуется таким способом институционализации конфликта, при котором одни индивиды или группы людей с помощью различных средств внешнего принуждения и манипулирования подчиняют себе сознание, волю, способности, собственность и свободу других в целях овладения и распределения ресурсов. Структура насилия строится на технике обесценивании его объекта, непризнании за ним каких-либо достоинств, прав, суверенности, на силовом принуждении к тому, что считает правильным или желательным обладатель ресурсов.

В «естественном государстве» управление конфликтами осуществляется с помощью принуждения и благотворительности за счет создания доминирующими группами ренты на основе ограниченного доступа к ресурсам. В социальном порядке «открытого доступа», который берет внутренние конфликты под демократический контроль, гражданам обеспечен равный доступ к управлению ресурсами за счет снятия правовых и экзистенциальных конфликтов между элитой и народом.

\section{Библиография:}

1. Аллисон Г., Зеликов Ф. Квинтэссенция решения. На примере Карибского кризиса 1962 года. - М.: УРСС: Книжный дом «ЛИБРИКОМ», 2012.

2. Арендт Х.О насилии. - М.: Новое издательство,2014.

3. Бек У.Общество риска. На пути к другому модерну. - М.: Прогресс-Традиция, 2000.

4. Вебер М. Избранное. Образ общества. - М.: Центр гуманитарных инициатив, 2012.

5. Дарендорф Р. Современный социальный конфликт // Иностранная литература. 1993. № 4.

6. З Зиммель Г. Избранное. Созерцание жизни. - М., СПб.: Центр гуманитарных инициатив, Университетская книга, 2014.

7. ̆ооа Х., Кнебль В. Социальная теория. 20 вводных лекций. - СПб.: Алетейя, 2011.

8. Козер Л. Функции социального конфликта : пер. с англ.О. А. Назаровой. - М.: Идея-Пресс; Дом интеллектуальной книги,2000.

9. Луман Н. Социальные системы. Очерк общей теории. - СПб.:Наука, 2007

10. Норт Д., Уоллис Д., Вайнгаст Б. Насилие и социальные порядки. Концептуальные рамки для интерпретации письменной истории человечества. - М.: Издательство Института Гайдара, 2011.

11. Павловский Г. О. «Система РФ в войне 2014 года. De Principatu Debili». -M.: Европа,2014

12. Сергеев В. М. Демократия как переговорный процесс. - М.: Московский общественный научный фонд, 1999

13. Турен А. Возвращение человека действующего. Очерк социологии. - М.: Научный мир, 1998

14. Шевцова Л.Мы: жизнь в эпоху безвременья. - М. : РОССПЭН, 2014

32 Луман Н. Общество общества .М.: Логос, 2011,С. 362-364

${ }^{33}$ Норт Д., Уоллис Д., Вайнгаст Б. Насилие и социальные порядки. Концептуальные рамки для интерпретации письменной истории человечества. - М.: Издательство Института Гайдара, 2011. 
15. Яницкий О Н. Социальные движения: теория, практика, перспектива. - М.: Новый хронограф, 2013.

16. Щупленков О.В., Щупленков Н.О. Трансформация власти в процессе построения гражданского общества в России // NB: Проблемы общества и политики. - 2013. - № 9. - С.20-88. DOI: 10.7256/2306-0158.2013.9.9053. URL: http://e-notabene. ru/pr/article_9053.html

17. Жежко И.В.. Политкорректность в контексте протестных движений // Тренды и управление. - 2013. - № 4. - С. 104-107. DOI: $10.7256 / 2307-9118.2013 .4 .7115$

18. Алейников А.В. Системные конфликты в России: концептуальные основания анализа. Статья II. // NB: Проблемы общества и политики. - 2013. - № 8. - C.1-47. DOI: 10.7256/2306-0158.2013.8.5109. URL: http://e-notabene.ru/pr/article_5109. html

19. Зайцев А.В. Диалогика Юргена Хабермаса: понятие и сущность // NB: Философские исследования. - 2012. - № 2. - C.7598. DOI: 10.7256/2306-0174.2012.2.148. URL: http://e-notabene.ru/fr/article_148.html

20. М.М. Назаров. Конфликтный потенциал сецессии (по результатам исследования в регионах) // Национальная безопасность / nota bene. - 2012. - № 5. - С. 104-107.

21. Р.Н. Пархоменко. Теория делиберативной демократии Ю. Хабермаса // Философия и культура. - 2012. - № 4. - С. 104107

22. Алейников А.В. Системные конфликты в России: концептуальные основания анализа. Статья II. // NB: Проблемы общества и политики. - 2013. - 8. - C. 1 - 47. DOI: 10.7256/2306-0158.2013.8.5109. URL: http://www.e-notabene.ru/pr/ article_5109.html

23. Алейников А.В. Системные конфликты в России: концептуальные основания анализа. Статья 1. // NB: Проблемы общества и политики. - 2013. - 7. - C. 94 - 140. DOI: 10.7256/2306-0158.2013.7.2306. URL: http://www.e-notabene.ru/pr/ article_2306.html

24. Зайцев А.В. Институционализация публичных дебатов во Франции и диалог государства и гражданского общества в публичной политике современной России: сравнительный анализ // NB: Проблемы общества и политики. - 2014. - 5. - C. 1 - 41. DOI: 10.7256/2306-0158.2014.5.12120. URL: http://www.e-notabene.ru/pr/article_12120.html

25. Герасимеца Б.. Взаимодействие гражданского общества и органов власти в Чеченской республике // Международные отношения. - 2014. - 1. - С. 25 - 30. DOI: 10.7256/2305-560X.2014.1.10354.

26. Зайцев А.В. Институционализация диалога государства и гражданского общества в контексте нормативной модели диалогической демократии // NB: Проблемы общества и политики. - 2014. - 7. - С. 64 - 82. DOI: 10.7256/23060158.2014.7.12541. URL: http://www.e-notabene.ru/pr/article_12541.html

27. Спиридонов В.В. Экономический подход к анализу причин политического конфликта на Украине // Международные отношения. - 2014. - 2. - С. 254 - 261. DOI: 10.7256/2305-560X.2014.2.11527.

\section{References (transliterated):}

1. Allison G., Zelikov F. Kvintessentsiya resheniya. Na primere Karibskogo krizisa 1962 goda. - M.: URSS: Knizhnyi dom «LIBRIKOM», 2012.

2. Arendt Kh.O nasilii. - M.: Novoe izdatel'stvo,2014.

3. Bek U.Obshchestvo riska. Na puti k drugomu modernu. - M.: Progress-Traditsiya, 2000.

4. Veber M. Izbrannoe. Obraz obshchestva. - M.: Tsentr gumanitarnykh initsiativ, 2012.

5. Darendorf R. Sovremennyi sotsial'nyi konflikt // Inostrannaya literatura. 1993. № 4.

6. Zimmel' G. Izbrannoe. Sozertsanie zhizni. - M., SPb.: Tsentr gumanitarnykh initsiativ, Universitetskaya kniga, 2014.

7. Ioas X., Knebl' V. Sotsial'naya teoriya. 20 vvodnykh lektsii. - SPb.: Aleteiya, 2011.

8. Kozer L. Funktsii sotsial'nogo konflikta : per. s angl.O. A. Nazarovoi. - M.: Ideya-Press; Dom intellektual'noi knigi,2000.

9. Luman N. Sotsial'nye sistemy. Ocherk obshchei teorii. - SPb.:Nauka, 2007

10. Nort D., Uollis D., Vaingast B. Nasilie i sotsial'nye poryadki. Kontseptual'nye ramki dlya interpretatsii pis'mennoi istorii chelovechestva. - M.: Izdatel'stvo Instituta Gaidara, 2011.

11. Pavlovskii G. O. «Sistema RF v voine 2014 goda. De Principatu Debili». -M.: Evropa,2014

12. Sergeev V. M. Demokratiya kak peregovornyi protsess. - M.: Moskovskii obshchestvennyi nauchnyi fond, 1999

13. Turen A. Vozvrashchenie cheloveka deistvuyushchego. Ocherk sotsiologii. - M.: Nauchnyi mir, 1998

14. Shevtsova L.My: zhizn' v epokhu bezvremen'ya. - M. : ROSSPEN, 2014

15. Yanitskii O N. Sotsial'nye dvizheniya: teoriya, praktika, perspektiva. - M. : Novyi khronograf, 2013.

16. Shchuplenkov O.V., Shchuplenkov N.O. Transformatsiya vlasti v protsesse postroeniya grazhdanskogo obshchestva v Rossii // NB: Problemy obshchestva i politiki. - 2013. - № 9. - S.20-88. DOI: 10.7256/2306-0158.2013.9.9053. URL: http://e-notabene. $\mathrm{ru} / \mathrm{pr} /$ article $9053 . \mathrm{html}$

17. Zhezhko I.V... Politkorrektnost' v kontekste protestnykh dvizhenii // Trendy i upravlenie. - 2013. - № 4. - S. 104-107. DOI: $10.7256 / 2307-9118.2013 .4 .7115$ 


\section{Политика и общество $9(117) \cdot 2014$}

18. Aleinikov A.V. Sistemnye konflikty v Rossii: kontseptual'nye osnovaniya analiza. Stat'ya II. // NB: Problemy obshchestva i politiki. - 2013. - № 8. - S.1-47. DOI: 10.7256/2306-0158.2013.8.5109. URL: http://e-notabene.ru/pr/article_5109.html

19. Zaitsev A.V. Dialogika Yurgena Khabermasa: ponyatie i sushchnost’, // NB: Filosofskie issledovaniya. - 2012. - № 2. - S.7598. DOI: 10.7256/2306-0174.2012.2.148. URL: http://e-notabene.ru/fr/article_148.html

20. M.M. Nazarov. Konfliktnyi potentsial setsessii (po rezul'tatam issledovaniya v regionakh) // Natsional'naya bezopasnost' / nota bene. - 2012. - № 5. - S. 104-107.

21. R.N. Parkhomenko. Teoriya deliberativnoi demokratii Yu. Khabermasa // Filosofiya i kul’tura. - 2012. - № 4. - S. 104-107

22. Aleinikov A.V. Sistemnye konflikty v Rossii: kontseptual'nye osnovaniya analiza. Stat'ya II. // NB: Problemy obshchestva i politiki. - 2013. - 8. - C. 1 - 47. DOI: 10.7256/2306-0158.2013.8.5109. URL: http://www.e-notabene.ru/pr/article_5109.html

23. Aleinikov A.V. Sistemnye konflikty v Rossii: kontseptual'nye osnovaniya analiza. Stat'ya 1. // NB: Problemy obshchestva i politiki. - 2013. - 7. - C. 94 - 140. DOI: 10.7256/2306-0158.2013.7.2306. URL: http://www.e-notabene.ru/pr/article_2306.html

24. Zaitsev A.V. Institutsionalizatsiya publichnykh debatov vo Frantsii i dialog gosudarstva i grazhdanskogo obshchestva v publichnoi politike sovremennoi Rossii: sravnitel'nyi analiz // NB: Problemy obshchestva i politiki. - 2014. - 5. - C. 1 - 41. DOI: 10.7256/2306-0158.2014.5.12120. URL: http:/www.e-notabene.ru/pr/article_12120.html

25. Gerasimetsa B.. Vzaimodeistvie grazhdanskogo obshchestva i organov vlasti v Chechenskoi respublike // Mezhdunarodnye otnosheniya. - 2014. - 1. - C. 25 - 30. DOI: 10.7256/2305-560X.2014.1.10354.

26. Zaitsev A.V. Institutsionalizatsiya dialoga gosudarstva i grazhdanskogo obshchestva v kontekste normativnoi modeli dialogicheskoi demokratii // NB: Problemy obshchestva i politiki. - 2014. - 7. - C. 64 - 82. DOI: 10.7256/2306-0158.2014.7.12541. URL: http://www.e-notabene.ru/pr/article_12541.html

27. Spiridonov V.V. Ekonomicheskii podkhod k analizu prichin politicheskogo konflikta na Ukraine // Mezhdunarodnye otnosheniya. - 2014. - 2. - C. 254 - 261. DOI: 10.7256/2305-560X.2014.2.11527. 